\title{
As Ligas Acadêmicas no Ensino Médico
}

\author{
Ernesto Sasaki Imakuma
}

As Ligas Acadêmicas Médicas (LAM) são parte quase que inevitável da trajetória do aluno na FMUSP nos dias de hoje. Praticamente todos alunos, ao fim dos 6 anos de graduação, têm em seu currículo uma passagem em uma LAM. Muitos alunos possuem dúvidas de quais cursos introdutórios fazer, já que muitos ocorrem na mesma semana e nos mesmos horários, tamanha a diversidade de opções. Hoje, devem estar ativas na FMUSP aproximadamente 50 LAM. O que estes alunos enxergam nestas entidades? Muitas coisas.

As LAM trazem um contato maior e mais precoce do aluno com o paciente. Alunos do ciclo básico não possuem tantas oportunidades de atender um paciente durante o curso formal. No entanto, possui muita vontade de fazêlo, visto que interagir com pacientes geralmente foi uma das motivações para ele ter escolhido medicina. As LAM permitem uma interação importante com o paciente, visto que a maioria delas foca em atividades assistenciais. Para o aluno do ciclo clínico ( $3^{\circ}$ e $4^{\circ}$ anos), é oportunidade para se aprofundar nas especialidades que lhe chamam atenção, conhecer melhor as doenças que foram só citadas ou vistas na nota de rodapé em alguma aula obscura, ampliar sua cultura médica e ter mais contato com residentes e médicos formados. Estas oportunidades parecem fazer diferença importante na vida profissional, visto que parece existir ligação entre a liga que o aluno fez e a especialidade que ele escolhe na residência.

Muitas ligas possuem a especial capacidade de entusiasmar o aluno em relação a alguma especialidade. O curso formal da FMUSP até o $4^{\circ}$ ano, em geral, por ser muito preso à sala de aula, pode ser entediante em muitos momentos. As LAM são o inverso, sendo caracterizadas por mais atividades práticas e menos aulas teórica. $\mathrm{O}$ apelo disto é inegável. Muitas ligas que trabalham predominantemente habilidades, quer cirúrgicas, como Liga de Técnica, quer clínicas, como a Liga de Apucuntura, tem altos índices de procuras. A graduação tem se atentado a este fato e mudanças no currículo visando trabalhar mais habilidades e menos teoria tem sido implementadas no curso formal, mas timidamente quando comparada às atividades das ligas.

As LAM podem ser ótimo ambiente para se iniciar iniciações científicas. Geralmente possuem tudo que é pre- ciso para iniciar uma: alunos interessados, professores e um ambulatório com pacientes. Eu mesmo me beneficiei muito da oportunidade de iniciar um trabalho científico dentro de uma LAM, sendo que minha tese de pós-graduação é meu trabalho desenvolvido como aluno durante as atividades da Liga de Anatomia Clínica. Considero uma oportunidade ótima para começar a se inteirar no método científico e que mais alunos deviam procurar ativamente os professores para iniciar projetos dentro das ligas de que participam.

As LAM oferecem oportunidade rara na FMUSP para ganhar experiência em gestão e administração. Muitos abrirão consultório após término da residência e terão que ter noções de como lidar com burocracias e transações financeiras. Ser diretor de uma liga traz a vivência, em menor escala, de como é lidar com estas circunstâncias e com o benefício de não causar enormes danos a si mesmo caso tudo venha a dar errado por inexperiência. Além disto, ser diretor de uma liga obriga o aluno a aumentar sua capacidade de comunicação, visto que ele tem como tarefa manter a estrutura destas entidades, que são formadas basicamente por recursos humanos, tendo como função ser o elo entre os alunos e também entre estes e os professores. E ainda tem que realizar o desafio de organizar um curso introdutório, cotando coffee-breaks, correndo atrás de anfiteatro, convidando professores e divulgando cursos, entre muitas outras tarefas para concretizar o curso. À primeira vista, estas atividades são consideradas menores e não ajudam ninguém a ser melhor médico. Tenho visão diferente. Elas treinam uma habilidade importantíssima na vida do médico, que é a capacidade de resolver problemas e enfrentar desafios fora de sua zona de conforto, circunstâncias tão pouco exploradas no curso formal e visivelmente necessárias a qualquer profissional.

Recentemente, um movimento a favor da melhoria qualitativa das LAM surgiu. Chamado de Projeto Ligas Médicas e desenvolvido junto ao Departamento Científico (DC) da FMUSP, pretende oferecer suporte administrativo para as ligas, além de estimular a criação de redes de cooperação entre elas. $\mathrm{O}$ foco é multiplicar oportunidades e alavancar a quantidade de projetos acadêmicos e científicos desenvolvidos através de plataforma em nuvem. A versão de testes, até o momento em que este texto foi escrito, já

Médico Residente (R2 - Geral) do Hospital das Clínicas da Faculdade de Medicina da Universidade de São Paulo.

Endereço para correspondência: eimakuma@gmail.com 
conta com a presença de 21 ligas da FMUSP e a versão definitiva está em processo de aprovação em instituição de fomento a projetos de inovação. Interessantemente, mesmo sem divulgação, ligas de outras faculdades do Brasil também aderiram à plataforma. Até argentinos (!) entraram em contato com o Ligas Médicas. Isto demonstra o interesse existente em um movimento deste tipo.

As LAM são entidades que parecem ser simples apêndices do curso médico, mas, se analisadas de perto, não o são. Possuem uma gama enorme de oportunidades, tanto para quem procura conhecimento ou para quem quer melhorar habilidades ou sair um pouco do ambiente do curso formal. Fico feliz que muitos alunos procurem as ligas para complemento de sua formação. Não se sabe exatamente que ganhos terão por participar das LAM, o que depende do próprio aluno, mas certamente haverá algo positivo da experiência, seja adquirindo novas habilidades, ganhando mais conhecimentos, fazendo projetos científicos, aprendendo a enxergar a medicina de outros pontos de vista, ou, no mínimo, ganhando mais oportunidades de se fascinar com a nobre arte que escolhemos como profissão. 